http://dx.doi.org/10.7833/119-1-1454

\title{
PSALM 80: AN EXEGETICAL DISCUSSION ON THE MODEL OF AN ABANDONED CHILD
}

\author{
Schalk Treurnicht \\ Department Old and New Testament \\ Stellenbosch University
}

\begin{abstract}
Psalm 80 uses a wide variety of metaphors to describe the way Israel saw God in their present context. This context is before the fall of Samaria to the Assyrians. It was a time of uncertainty, with many questions on God's role in Israel's future and God's role in their present suffering. They may have asked, are they suffering because God has forgotten or abandoned them? Due to the uncertainty the psalm, which is a communal lament, asks God not to forget them and to return to them. This is done by referring to God's past relationship with Israel, reminding God of the good parent-child relationship they once had.

In Psalm 80 different metaphors work together to create this model of parent and child, with God portrayed not as a good parent, but rather a wicked one. But all is not lost, and Israel knows their lives can be saved by God choosing to return to them and to become, once again, the good parent, who keeps them safe. In this exegetical discussion on Psalm 80, I want to use these metaphors to help develop this model of Israel as an abandoned child and to conclude with the image that this portrays. The metaphor of Israel as child does not appear in Psalm 80, thus, the different metaphors that do appear, each say something about the relational experience Israel had with God. These experiences will be used to flesh out/ add depth to this understanding of Israel as an abandoned child.
\end{abstract}

Keywords: Psalm; Metaphor; Model; Child; Abandoned; Lament

\section{Introduction}

Psalm 80 is a passage that uses a wide variety of metaphors to describe the way Israel saw God in their present context. This psalm is set in the Northern Kingdom in the time before the fall of Samaria to the Assyrians, the time of King Hosea, the last king of Israel. For the Israelites it felt like God was not listening to them, He was not present, and they saw destruction looming. Thus, in this communal lament, Israel is calling out to God, reminding him of the Exodus event, with the hope that He will return. These metaphors that portray the child Israel calling to its parent God builds up an image of an abandoned child who feels cast aside and vulnerable. In this article I want to add detail to this model of an abandoned child by looking at the different metaphors found in Psalm 80. To do this, I start with a short discussion of metaphors and models to show how the theological discussion will be informed, before the model can be built at the end of the article. The exegetical pattern that will be followed, is a literary discussion, a historical discussion, a theological discussion and, to conclude, the more complete model of Israel's relationship with God. 


\section{Metaphors and models}

When reading the Bible, it is clear that many metaphors are used to describe God and Israel. These metaphors are important because they help us understand both Israel's understanding of God and how they saw themselves in their relationship with God. This means that metaphors matter, as Fretheim (1984:1) confirms, for without metaphors Israel would not have been able to say anything about God and very little about a relationship with God. Thus, the importance of metaphors cannot be denied, and many scholars have written about this. The most well-known scholars on biblical metaphors are S. McFague and M. Soskice.

Within the study of metaphors, scholars ${ }^{1}$ commonly agree that metaphors are used to share information about something less known by comparing it to something better known. Thus, when reading biblical texts, we should try to determine what was well known to the writers to help us understand that which was less known. Thus, a cognitive connection is made between the conventional wisdom of the day and that which the metaphor is trying to describe. For example, Israel's understanding of a parent-child relationship feeds their understanding of how their own relationship with God should be understood. Together with the cognitive connection, there is an emotional connection when a relational metaphor is used. McFague (1982:44), for example, reminds of the emotional connection made when speaking of God as a father. Different readers will hear the metaphor differently, depending on their own personal experience regarding their own father. Someone with an abusive father will hear it differently to someone with an affectionate father. A father might hear the metaphor differently when read in relationship with his own child. But these metaphors do have limits in terms of the information they can share and thus a model built out of different metaphors, needs to be positioned. Therefore, instead of speaking about God as "father" and Israel as "child", we should refer to the fatherhood or motherhood model and the model of sonship or daughterhood. These models contain different metaphors that add to their meaning. Thus, different metaphors come together to make a model. A model says more than a metaphor, but still not everything, because God cannot be fully explained, neither can God's relationship with Israel and the world. Psalm 80 is an excellent example of this, because the concept Israel as "child" does not appear in the psalm, but metaphors can suggest such a relationship.

Both McFague and Soskice have written on biblical models; for this article McFague's (1982) use of models will be used. I will summarise her stand. A model is a metaphor that gives birth to new metaphors, for example one can speak of God the parent or Israel as God's child, but when this idea is expanded on, it becomes a model of parenthood and sonship. Models are mostly used with relational metaphors, for they have more depth than the metaphor of God as a rock, for example. The depth of a model builds tension between the "is" and the "is not", for not all characteristics are applicable to God. For example, God as a parent should have the characteristics of love and affection and not other human characteristics such as being neat or liking pizza. It is important to keep this in mind when speaking about God, the Completely Other, for it is dangerous to transfer too many qualities and characteristics to God, thus more "is" than "is nots". To

Authors that reference this type of thought on metaphors are: Lakoff and Johnson (1980), McFague (1982),

Greenstein and Preminger (1986), Soskice (1989) and Macky (1990). 
quote McFague (1982:24) on this, "But they are also dangerous, for they exclude other ways of thinking and talking, and in so doing they can easily become literalized, that is, identified as the one and only way of understanding a subject".

Thus, in the exegetical study to follow, the metaphors of Psalm 80 will be used to help build the picture of Israel as an abandoned child. Throughout the Old Testament Israel is referred to in both male and female genders. For this article the more neutral term child will be used, while the emphasis is on the abandonment more than the child. At the onset of the discussion the model is already in place, but "empty", ready to be filled with metaphors. By this I mean that the model of God as a parent is well known, but the metaphors and characteristics that flesh out that model, are not necessarily known. Thus, more emphasis will be placed on the content of the model than the justification of it.

\section{Psalm 80}

\section{MT and English Standard Version}

80

To the choirmaster: according to Lilies. A Testimony. Of Asaph, a Psalm²

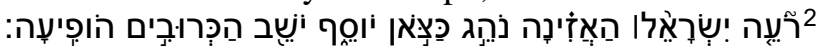

${ }^{1}$ Give ear, O Shepherd of Israel, you who lead Joseph like a flock. You who are enthroned upon the cherubim, shine forth.

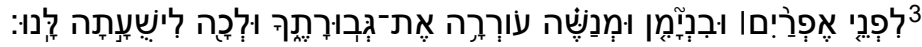

${ }^{2}$ Before Ephraim and Benjamin and Manasseh, stir up your might and come to save us!

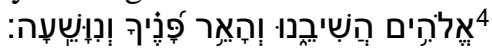

${ }^{3}$ Restore us, O God; let your face shine, that we may be saved!

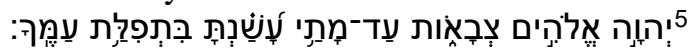

${ }^{4} \mathrm{O}$ Lord God of hosts, how long will you be angry with your people's prayers?

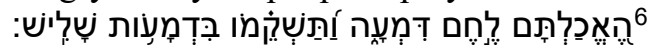

${ }^{5}$ You have fed them with bread of tears and given them tears to drink in full measure.

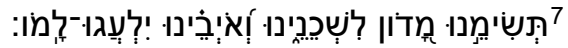

${ }^{6}$ You make us an object of contention for our neighbors, and our enemies laugh among themselves.

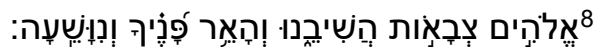

${ }^{7}$ Restore us, O God of hosts; let your face shine, that we may be saved!

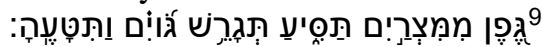

${ }^{8}$ You brought a vine out of Egypt; you drove out the nations and planted it.

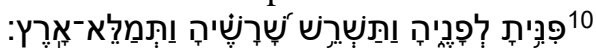

${ }^{9}$ You cleared the ground for it; it took deep root and filled the land.

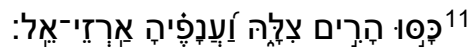

${ }^{10}$ The mountains were covered with its shade, the mighty cedars with its branches.

12

${ }^{11}$ It sent out its branches to the sea and its shoots to the River.

13

2 LXX adds $v \pi \varepsilon \rho$ $20 v \alpha \sigma \sigma v \rho เ o v$ to place the psalm in a context. 
${ }^{12}$ Why then have you broken down its walls, so that all who pass along the way pluck its fruit?

$$
\text { : }
$$

${ }^{13}$ The boar from the forest ravages it, and all that move in the field feed on it.

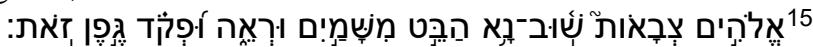

${ }^{14}$ Turn again, $\mathrm{O}$ God of hosts! Look down from heaven, and see;

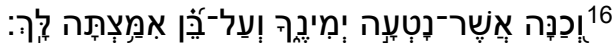

15 the stock that your right hand planted, and for the son whom you made strong for yourself.

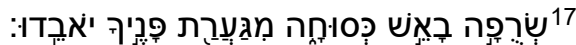

${ }^{16}$ They have burned it with fire; they have cut it down; may they perish at the rebuke of your face!

18

${ }^{17}$ But let your hand be on the man of your right hand, the son of man whom you have made strong for yourself!

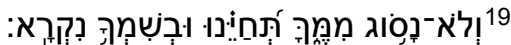

${ }^{18}$ Then we shall not turn back from you; give us life, and we will call upon your name!

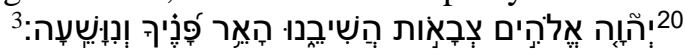

${ }^{19}$ Restore us, O Lord God of hosts!

Let your face shine, that we may be saved!

\section{Notes}

\section{Structure}

Different structures have been proposed for this psalm. Briggs and Briggs (1906:202) use the refrains to break the psalm into parts. Gerstenberger (2001:103) and Hossfeld and Zenger (2005:309) also use the refrains, but each of these authors differ on the number of refrains. Thus, the refrains play an important role in the structure of the psalm.

A different approach to finding the structure of this psalm was put in place by Westermann (1981:53-54), who uses the different parts of a communal lament. He states the structure is similar to both Psalm 74 and 79, as they have the same elements. Tate (1990:308) also adheres to communal lament, but tries to combine it with the refrain structure.

The structure of the psalm, according to Gaebelein and Polcyn (1991:524), is as follows: Prayer for deliverance in vv. 1 to 3 . The Lord's present anger in vv. 4 to 7 . The Lord's past mercy in vv. 8 to 14a. Prayer for deliverance in vv. 14b to 19. Gaebelein and Polcyn see a A B B A structure in which the refrain does play a role. This study follows this structure, which keeps to the metaphors of the psalm but notes that v. 15 is important in the overall structure.

\section{Refrain}

In the discussion of the structure of the psalm, the uncertainty of scholars regarding the refrain was already indicated. Briggs and Briggs go to great lengths to justify their

Biblia Hebraica Stuttgartensia: With Westminster Hebrew morphology. 1996, c1925; morphology c1991 (electronic ed.) (Ps 80:1-20). Stuttgart; Glenside PA: German Bible Society; Westminster Seminary. 
imposed structure by using the refrains. Most scholars disagree with adding an extra refrain after v. 10, but the use of v. 14 as a refrain seems more appropriate. Dahood (1986:255), for example, states that vv. 3, 7, 14 and 19 are the psalm's refrain. Rofe (2011:308-309) also uses v. 14 as a refrain, in order to end the third stanza and to ensure that there is an even rhythm and a uniform length to the stanzas. But in so doing, the

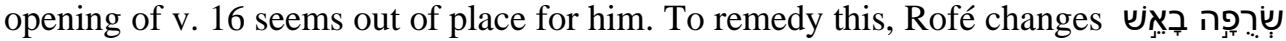

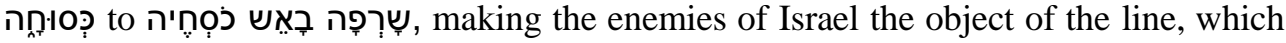
gives extra emphasis to the rebuke of God's face in the second part of the verse.

Gerstenberger (2001:103-104), on the other hand, states that adding another refrain after v. 10 is not necessary. He continues to say that using v. 14 as a refrain is not stylistically or thematically appropriate, due to differences in content, imagery and vocabulary with the refrains of vv. 3, 7 and 19. Furthermore, the first-person plural of the refrain fits well into a congregational worship setting, which vv. 14 and 15 do not .

If vv. 3, 7 and 19 are used as the refrain, the next question is whether it was part of the original or not. Hossfeld and Zenger (2005:311) state there are five reasons why the refrain could be the work of an editor. Firstly, the refrain is similar to Jerusalem temple theology. Secondly, the refrain implores God to act within the community, while it also states that God should look down from heaven; thus, there is a separation between God and community. Thirdly, the difference between v. 14 and the refrain would be easier to understand if they were written by different people. Fourthly, the refrain does not share the perspective of an enemy threat, which is emphasised in the rest of the psalm. Lastly, the psalm would also flow naturally without the refrain, thus ending with v. 18 .

The chosen structure of Gaebelein and Polcyn entails that v. 14 be understood as part of the refrain. The theological significance of the refrain will be discussed below.

\section{Historical time and context}

Placing Psalm 80 in a certain time and place has led to a variety of different opinions. The LXX makes the note $v \pi \varepsilon \rho$ subscription to indicate a Northern origin, probably before the destruction of Israel in 722 BCE. Many scholars follow this assumption based on the tribes named in the opening verses of the psalm. This might be true of the original psalm, but it is probable that an editor made some adjustments in the post-exilic time. Briggs and Briggs (1906:201) ascribe the editorial work to a group in the Maccabean period, who added a prayer of imprecation of the enemies in v. 16 and the Messianic petition in v. 19.

The subscription that ascribes the psalm to the Asaph group has also been used to place it in a certain setting. Jasper (1967:54) links this reference to a cultic group of prophets in Jerusalem. This group's name is derived from the seer Asaph, who is mentioned in 2 Chron. 29. Some of the psalms ascribed to this group are post-exilic, but some could also be ascribed to cultic prophets in Israel in the time of the monarchy. Rendsburg (1990:73) argues for a Northern origin of the Asaph psalms. He notes the repeated mention of Joseph and Ephraim, together with Benjamin and Manasseh in Psalm 80. Thus, it can be noted that the Asaph group has been placed in both the North and the South.

The mention of the different tribes has also been used to emphasise a Northern origin. Hossfeld and Zenger (2005:311) place the original psalm in the Northern Kingdom due to the references to the tribes, which are understood to be the core of Israel. The possible 
date then lies between 732 and 722 BCE with the initial integration into the Assyrian province and the later annexation of the core of Israel by Sargon (Hossfeld and Zenger 2005:311). Dahood (1986:255) agrees with a Northern origin for the psalm and adds that the lament comes from the last days of the Northern Kingdom, before its destruction in 721 BCE.

Thus far it seems clear that the psalm originated in a cultic context. If it is from the North before the fall of Israel, the possibility of destruction has reminded the tribes of their common responsibility, born out of the acts of God in their past, to hold joint cultic celebrations even after the severing of the tribes. Ancient traditions are recalled, with the calling on the God of the Ark, the one enthroned upon the cherubim (Weiser 1962:548). This idea is supported by the communal nature of the psalm and the refrain which the people of the community could sing, while the priest would sing the other strophes (Tate 1990:309). The poetic skill evident in the psalm suggests it was written by a group of theologically educated cultic leaders (Hossfeld and Zenger 2005:311). If it were used in a cultic setting, it could have developed over a period of time, probably at a yearly commemoration of past defeats. This annual commemoration would then make use of the different voices, the hymnic attributions and the poetic parable to help the flow and remembrance of the psalm (Gerstenberger 2001:106). The question "how long?" does indicate that the crisis persisted over a long period of time, probably after the community started to feel that their prayers were ineffective (Broyles 1989:161). If the psalm did originate in a strong cultic setting, then it would have originated in the capitals of either the Northern or the Southern Kingdom.

From this discussion it is clear that the psalm played an important role within the cultic setting of a lamenting community. The refrain would then have been an important part of communication between the people and God, with the priest leading them in a lament before God. For this study it is accepted that the psalm originated in the Northern kingdom before its fall. Thus, a cultic setting in Samaria, with the Assyrian threat looming. The community turned to God in hope of salvation and restoration. The model that is portrayed, gives expression to what they were or are currently experiencing from God. This might be what they needed or not, yet they still continue to chant the refrain in the hope of God reacting in a way favourable to them.

\section{Theology}

The psalm's context of conflict and lament regarding impending destruction brings with it the idea of a military God. The traditions found in the psalm regarding God's saving acts of the past, are firmly rooted in Israel's salvation history and thus the psalm understands God as the Lord of hosts who is active in warfare. The call to return and to renew the covenant relationship, is the focus of the psalm, bringing with it the story of Egypt and the promised land. In the current context the community is facing a trial of faith, feeling that they are separated from God, who is angry with them and, therefore, He keeps silent. This silent anger of God influences their life of prayer. This creates the problem of knowing that the way they reach out to God, is also the reason they are estranged from Him. God appears not as the helper, but rather as the adversary, with the community experiencing anger when they were expecting comfort (Weiser 1962:548). The community still prays to the angry God, trusting that God will do what no human can. This act of faith emphasises the paradox of faith, where the God who chastises, is 
also the God who heals. Weiser (1962:549) states that the symbol of the vine has its origin in Canaanite religion. The use here, he says, connects the two realms of nature and history, to express together God's goal to save again. Thus, it is not a sad recollection of what happened in the past, but rather a new meeting between God and his people reminding them of their salvation as they participate in the cult. The past and present become entwined as God's presence then and now comes into question. The call for God to look down, places emphasis on the feeling of distance between God and his people. Their petition is addressed both to the one who delivers and the one who afflicts. Thus, both these antitheses are found in unity in God's character, with his people unaware of the educational purpose hidden within their suffering (Weiser 1962:550). Weiser's broad summary of the theology of this psalm is a good basis from which to start and to delve deeper into its theological insights. His summary shows the lamenting character of the psalm, with the people praying and feeling that they are in a trial of faith. The idea of God being responsible for their current situation, is a crucial part of their worldview, and

the fact that they call on God to return, emphasises the trust they have in a mighty Lord of hosts, who can restore them. It is, thus, the paradox of calling on the parent who rejected the child, to return and take the child up in his arms and to fight for the child he once cast aside. The only action available for the child is to remind himself of how God acted in the past, by reciting past stories in current metaphors, mixing metaphor and lament, to help in their present conflict.

\section{Title to verse 2}

Basson (2005:209) explains the shepherd metaphor of God as a relational one. In the ancient context shepherds were responsible for the physical wellbeing of their own sheep or the master's sheep. When threats such as thieves and predatory animals were present, the shepherd would have to place himself in harm's way to ensure the safety of the sheep. This is what the God-Israel relationship should be. Tate (1990:313) calls this title for God, "one of the great titles for Yahweh" and says the shepherd metaphor is one known in the Old Testament, though the term Shepherd only appears here and in Psalm 23 in the Old Testament. However, the metaphor does occur in the blessing of Jacob for Ephraim and Manasseh in Gen. 48:15. This means the metaphor, or rather the idea of a shepherd, was well known but not used often.

In vv. 1-2 there is a balance between recalling God's acts of the past, in the form of praise, and imploring God to act now, in the form of imperatives. These reveal parts of God's "nature": Firstly, as has been stated, the shepherd metaphor was well known in the ancient Near East, especially in connection with deities and kings. But this is also the reason why God is not often called by the title of shepherd in the Hebrew Bible. In this passage there are appeals to the shepherd's professional duties of feeding and protecting. There are also appeals to the characteristics of the "good" shepherd, who shares his life with the sheep, being intimately involved with them. Secondly, the emphasis on leading Josef reaches back to the Exodus narrative when Israel took control of the land. The connection that is made between God leading Israel and God being enthroned between the cherubim connects God to the King who rules from the heavens. In the Northern Kingdom this could then be applied to a warlike god-king, with the connection of the exodus and the occupation of the land. The imperatives in vv. 1-2 call on God to come from heaven and use his military might, to bring salvation (Hossfeld and Zenger 
2005:312-313). Thus, the shepherd metaphor, which includes feeding the sheep and protection, has a caring quality. The good shepherd would be feeding and protecting the sheep, while being in an intimate relationship and maybe even knowing the sheep by name. But it does not end there. There is also the warlike side of the shepherd's care, going into battle to protect his flock. God's acts of salvation in Egypt are the example they long for. They long back to having God present between the cherubim, ready to take up arms and bring salvation. Thus, the psalm opens by describing the good shepherd model, for whom the psalmist longs.

The imagery of being between the cherubim, Tate (1990:313) states, has three meanings: "(1) the mobility of Yahweh, who comes to his people in times of need and manifests his power in deeds of deliverance; (2) the divine warrior who rides his throne chariot across the heavens and through the storm to save; (3) the one whose great wings provide relief and protection for those who are under them." Together with this, the four imperatives of the introductory verses parallel the exodus story very well. When God calls Moses in Ex. 3:7-8, God uses the words "seen", "heard", "concerned" and "come to lead". Thus, the writer is referring to a strong traditional basis of faith, hoping for God to appear in his theophany glory, as He did in Israel's past. He is the warrior who also cares for his flock and the shepherd who takes up arms. This is the metaphor Israel calls upon, in remembrance and in expectation. They use the stories of old and mix them with the historical narrative of the ark to call upon their God, the one who can save and care for them. For a child, the two most important concerns when abandoned, would be: who will feed me and who will protect me? God is placed in the position to do both. Remembering the influence of a strong parent figure, helps a child feel safe. The metaphor expands the model of the abandoned child by reminding the reader of the fond memories Israel has of the past. The child must look back into the past to gain confidence. Remembering the past, brings comfort. The child remembers the good shepherd and the loving parent, while experiencing the wicked shepherd and the abandoning parent. The idea of a wicked shepherd is known among prophets in the Old Testament. The model emphasises the contrast between expected and experienced; the "evilness" of the shepherd who chooses not to fulfil the role he is supposed to, while Israel is helpless to save themselves.

\section{Refrain}

The refrain that is repeated in vv. 3, 7 and 19 has received a lot of attention in attempts to place the psalm. The most prominent of these is the cultic use of the psalm, with the refrain being the chant of the people, while the priest leads them through the lament. The refrain is where the people pray for restoration and for God to restore the covenant mercies they heard of in the past. The people have broken the covenant and for this reason God has become angry with them. In the refrain God is called to deliver his people and to bless them (Gaebelein and Polcyn 1991:524-525), rather than to act out his justified wrath.

Brown (2002:86) emphasises the sanctuary setting from where the solar imagery of light is used to show God's presence. This presence is connected to the deliverance of Israel. The metaphor of light or, in Psalm 80, to shine, is used in many ways in psalms. Light can guide the psalmist's path, it can expose hidden sins, it can be used to ensure victory and to convey the idea of agricultural bounty. Furthermore, light is connected 
with the joy of the righteous and allows humans to see, which indicates life, where darkness only leads to death (Brown 2002:198). The refrain shows confidence that God's choice to shine, will ensure victory.

The refrain in v. 3 is possibly from the Jerusalem temple cult and refers to the wellknown Aaronic blessing from Numbers 6 . An amulet found in a tomb in Jerusalem dating from the $7^{\text {th }}$ or $6^{\text {th }}$ century BCE attests to its popularity. The connection made, is that shining is proof of God's favour and communicates the saving acts of God who shines. It is visible in the initial imperative for God to "restore us"; a movement back to the fullness of life which they once had, and away from the distress they are currently experiencing. This movement is both national and religious, firstly, calling on God to liberate the fallen Northern Kingdom, and secondly, pleading for restoration of the relationship that once was (Hossfeld and Zenger 2005:314). Hossfeld and Zenger, who set the original psalm in the North, note the importance of the idea of God shining on someone, with reference to the Keteph Hinnom amulet. Returning to God's favour and, with that, also being restored to the place where one belongs, a promised place in the covenant, is very important when a relationship needs to be mended. This can be linked to a child seeking to regain the favour of a parent after disobedience, knowing the favour means liberation and restoration.

From the above it is clear that shining has a restorative impact, by restoring Israel to the covenant, but also a military impact, by ensuring victory. In this text it seems clear that shining has a direct connection to liberation, with the hope of an exodus-like intervention by God. This would mean that, due to God seeing His people suffer and God remembering that He loves his people, He would once again intervene and save them. Thus, love leads to shining and shining is a blessing of liberation, which is enacted by God's military force, destroying those who oppressed his people. Thus, the military god-king found in the opening verse, enthroned between the cherubim, is being called to war, to make his destructive might shine on the enemies of his people.

\section{Verses 4-6}

The question of v. 4 asking how long, has been interpreted in different ways. It is important to note the question is not, why are we being punished?, but, how long will it continue? Israel is not questioning the decision to punish, but rather the duration of the punishment, wondering how long God's anger will be set against them and when will God turn back to give them proper food to eat and water to drink, as in the Exodus narrative. Asking how long also rejects any notion of God being incapable of saving his people, with the idea of God standing against the deities of other nations (Hossfeld and Zenger 2005:314). Thus, the question is not if God can save, but rather how long, for it is necessary for God's anger to lessen and the smoke of his wrath to disperse for the light to shine and for the restoration to happen.

In vv. 5-6 the lament intensifies with accusations against God, for acting contradictory to his supposed nature of a good shepherd. Instead of leading the flock to green pastures, He gives them tears; instead of living water, they are left to drink tears in full measure. These are not the acts of a good shepherd, but rather a wicked shepherd, who leads his flock to suffer and to be persecuted by their enemies (Hossfeld and Zenger, 2005:315). Israel's experience has moved from past to present, from the good shepherd to the wicked one. Israel is expressing its vulnerability, unable to care for itself and 
forced to eat and drink tears. The use of the Hiphil in v. 5 makes God the subject of the verb who forces Israel to consume their tears as bread, heightening God's responsibility for Israel's present distress, which is visible throughout the psalm. In Psalms 42 and 102 the same idea of consuming one's tears occurs, but in these two psalms it is the people who are the subject and thus personally responsible for eating tears. The communal suggestion of these psalms is a high frequency of weeping, with weeping being as much a habit as eating. The felt distress connected with weeping in these psalms is the experience of abandonment and isolation from God. This motive is used to indicate the felt distress and the need for a relationship or renewed attachment (Bosworth 2013:43). This picture illustrates the consequences for a child who is abandoned. The child is not fed anything of sustenance and not growing strong, nor is the child able to defend itself. The rejecting parent is the guilty party. He is responsible for the weeping day after day. Westermann (1989:30) reminds that vv. 5 and 6 do not speak explicitly about suffering, but rather about the effects of suffering on the community. In the context of the Old Testament, suffering was suffering in the community and contained an element of disgrace. Even those with whom Israel had a neutral relationship would see their suffering, and this would leave scars just as those inflicted by the enemy; a harsh reminder that rejection is not something only two parties share in, but that rejection is a very visible reality and this makes the vulnerable party even more so, exposing the child to those who enjoy his hardship. The model is expanded on once more by the abandoned child being left malnourished, left to weep day in and day out. It might also be said that the child grows bolder in his words, intensifying the lament with accusations.

God's actions in this psalm do not seem unjust, but the duration and intensity of this oppression does beg the question, how long?, and it leaves the people with feelings of abandonment or wondering if God has chosen to reverse what He started in Egypt. The laments in vv. 4, 5 and 6 each touch on a certain sphere of a person's life. Prayers in v. 4 indicate the religious life, while the food reference in v. 5 indicates personal life, and then the reference to neighbours and enemies in v. 6 connects to the social sphere (Broyles 1989:162-163). Israel is experiencing its current distress in all possible forms. Distress is all they are experiencing, and they are praying for light to be restored to their lives. They move once again to chant the refrain in v. 7, adding צִבְאָוֹ, of hosts, maybe to emphasise the military necessity of God's intervention, maybe to remind themselves how small they are, or maybe to state their confidence in God's power over the enemy. The chant may be louder now, as they grow desperate for the intervention. It might be soft due to exhaustion and malnourishment. But the chant does not end.

\section{Verses 8-14a}

After the second refrain, the psalm moves to the parable of the vine. For Westermann (1989:34) it is important to note that the two metaphors of shepherd and vine grower both come from the natural environment that the Israelites know so well. It is expected of God to act in these ways; thus, the writer is speaking a reality for the community. These metaphors are part of Israel's understanding of life and thus they are employed when things are not as they would want them to be.

The movement from shepherd to vine grower retains the same idea of a contradictory God, who is not dealing with them as a royal leader should. The metaphor is firstly used to remind God of the past, where his saving care led Israel out of Egypt into the promised 
land, where they could grow strong and become a mighty nation. But in v. 12 there is a change and the writer asks, why? This "why?" does not seek a fixed answer or a report, but simply expresses the feeling of incomprehension. The present context is described, and it seems clear that God is to blame. The vine grower is being reminded of how the vine was planted and grew under his care and the writer wants to use this to motivate the vine grower to return to his divine identity, his saving identity. It is in remembering the past that the necessary passion and power for the present triumph can be summoned (Hossfeld and Zenger 2005:315). As a malnourished child can still ask, how long?, so a disregarded and physically afflicted one can ask, why?, as an expression of confusion, not understanding or not being able to see any light in the present.

This vine imagery is well known as a symbol for God's people. Jacob uses this term in his blessing of Joseph, and in Isaiah this imagery is also beautifully employed. God's active care lets the size of the vine grow from the Mediterranean to the Euphrates river, signifying the stretch of David's kingdom (Tate 1990:314-315). The writer emphasises God's active part in this flourishing time in Israel's history by using God as the subject

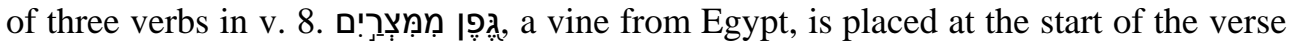
for emphasis, but the three following verbs are all in the second person singular form to clearly show it is none other than the vine grower at work, none other than God himself who is playing an active role in the history of Israel. He is the one who brings the vine, who drives away the enemies and who plants the vine. This blessing of the past has

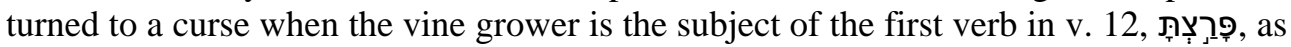
the one who broke down her hedgerows.

Israel as the vine does not only feel she is being plucked out, or devoured by force, but fed on by all that moves, maybe even the tiniest insects. Whitekettle (2005) states the insects graze on the foliage, meaning that all forms of destruction occur. The roots planted by God are being fed on, ground and roots are pulled apart and the fruit of its branches are all plucked off. The lamenter's strength at this point is not enough for a full refrain, but only for the pleading imperative followed by a short interjection, return now! The model of the abandoned child is expanded by the metaphor of a destroyed vine. The child is not only left weeping and malnourished, but also hurt and beaten. The protection of the parent is gone, leaving the child vulnerable to all who pass by.

\section{Verses $14 b-19$}

The big question in the last section is, who is this "son" or "son of man"? Are they the same or different persons? Is the one Israel and the next one the king, or does it first refer to the king and then the messiah? Augustine, in his answer to the Jews, interprets the son of man in v. 18 as a messianic reference (Wesselschmidt 2014:141). The translator of the LXX also understood v. 17 to be a messianic reference and translated v. 15 the same, to agree with v. 17. Tate (1990:315) states v. 15b's reference to the son is probably to Israel and the term could have been placed there by a redactor to bring the kingship language of v. 17 into the discussion of the vine, connecting this metaphor with the preceding verses. Hill (1973:266) connects the reference to the Davidic kingship and the establishment of the son-father relationship found in 2 Samuel. The strengthening is then understood to be God's help and faithfulness, which allows the king to do the task God has set for him. This continues the idea of using kingship language and sees it as a 
reference to a king specifically and not to a messiah. Hossfeld and Zenger (2005:316) connect the v. 17 references to "man of your right hand" and "the son of man" to King Josiah. The verb "to strengthen" also connects to the strengthening of the king. They continue to say that the son of man reference does not have a specific connotation in royal theology, but here in the psalm it is implied or suggested. Westermann (1989:33) states the reference to "man of your right hand" is a reference to Israel and not to a king. Lastly, Gaebelein and Polcyn (1991:527) see a Davidic messianic connotation in v. 17, stating that Israel's hope is grounded in this messianic figure and through this figure God's redemptive purposes will continue, regardless of what might befall Samaria or Jerusalem. Thus, all three possibilities have been put forward by scholars.

A choice needs to be made regarding the context within which the text originated. If the psalm did originate in the North before the fall of Samaria, then the question is whether the son could simply be a king in the line of David and not the messianic figure found in Daniel and other post-exilic texts. If this is not possible, with the text originating in the North before the fall of Samaria, then the son reference must be to Israel, with whom God has been actively involved in the past. In this study the terms "son" and "son of man" are understood to refer to Israel, considering the metaphors of the shepherd and the vine grower. In both these metaphors the active involvement of God is bringing up Israel and leading the way forward, like a parent would his own child. The image gained from this is an abandoned child, saying to the abandoning parent that the parent once made the child strong and now their relationship needs to be restored.

In v. 16 the writer moves from God to the neighbouring nations, who also played a role to bring about the current crisis. The imagery of fire correlates with the destruction of the cities and the burning of the countryside. The call is, thus, to motivate God to a

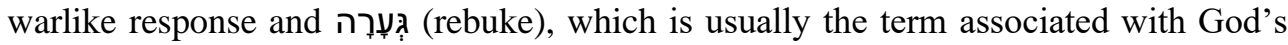
battle against the chaos powers, to protect and to keep order in the world (Hossfeld and Zenger 2005:316). Thus, this call is to reverse the present context, to clear away the insects, to slaughter the boar and to not let those who pluck at the vine, pass by. The fire and the cutting axes need to be put to use against those who are currently using them and the mere presenting of God's face, his presence, would be enough to ensure this. The abandoned child still believes in the Parent's strength. This has not changed, and the Parent only needs to return for the child to be saved once again.

The last petition in v. 18 is only applicable if God does indeed shine favourably upon Israel. If God does not, then there is no future nation to be loyal to God and thus no one to call on his name. Hossfeld and Zenger (2005:316) note the aspects of Israel's selfconcept in v. 18, which are interwoven in this verse. They say "(1) Israel knows that its life is the gift of its God; the shepherd imagery emphasizes this in the psalm. For that very reason Israel struggles in this psalm for the (renewed) care of its God. (2) Life, for Israel, is above all life in the dimensions of freedom and well-being; the vine imagery in the psalm emphasizes this aspect. (3) Israel sees it as its 'life task' to give witness to YHWH's Godhead in the world of the nations; the vow of praise emphasizes this aspect: "that we may call upon your name." It is certainly correct that if God does not intercede, then there will be no nation to call upon his name; no child for the parent to look towards and to see if it is broken or well and no child to restore to wellbeing and to carry on the parent's name. Hossfeld and Zenger might be over-extending the idea of Israel's selfunderstanding, but it is good that they connect the shepherd and vine metaphors with the 
concept of "us", stating it is the flock and the vine that need to be restored, and the flock and the vine who call upon God's name. The model of the abandoned child is expanded by reminding the readers that they still trust in their parent. They still believe that the parent's return is possible and then they will be saved, and their enemies will perish. The child uses the past to remind the parent of how He made the child strong, and this is also why the parent should return, because the relationship is not completely lost.

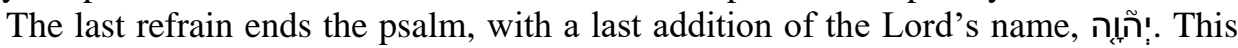
might be in connection with the end of v. 18 or just a poetic addition to the growing emphasis on the one called upon. The importance of this last refrain is its fullness. The full title of God is used, maybe to show God's importance to Israel, to hold up as a warning to the other nations, or as the last reminder that the parent who abandoned, is not just another parent, but the Lord, God of hosts.

\section{Model of an abandoned child}

Psalm 80 is a communal lament which uses God's saving acts of the past to bring comfort to Israel in times of crisis. The context has reminded Israel that they need to repent and to remember how their relationship with God once was. They have sinned and God is rightfully punishing them, but for too long and too harshly. The child is feeling the parent's wrath too intensely and thus calls on the parent to return, to take the child up in his arms again and to restore their relationship.

The abandoned child was once a loved child, who was raised well and grew robust. The parent-child relationship was once healthy, with the parent helping the child grow stronger, protecting the child and being ever present as the child grew up. But now things have changed. The child has transgressed the law and the child knows it deserves punishment, but the punishment has persisted too long, and the child fears the parent will not return in time, before the child is destroyed. This feeling of separation leads the child to call his parent to look down and see his pain. The child's prayers go unanswered, as he lies weeping, his tears coming more often than food, his body malnourished and his bruises visible to everyone. The child is embarrassed, hearing the laughs of those who were once neutral and now knowing there is nothing left for anyone to take. Every aspect of his life seems to be in ruins: religious, personal and social, all seem to be broken beyond repair. But still the child knows the relationship is not completely lost and the memories of how things once were, keep him going, makes him bold enough to keep pleading. There is still belief in the parent's military might, with the child pleading for the parent to return to shine, for this will protect him and bring him back to the relationship he and his parent once shared. The child keeps hoping, keeps pleading for the parent to hear and to return.

\section{Conclusion}

The metaphors in the psalm build a relational model of God. This means that in the relationship with God, as expressed in this model, both God and Israel have a voice. The voice is not only from God to Israel, but also from Israel to God, and Israel may accuse God. The accusations Israel makes against God in the communal lament, is that they are not experiencing God as they remember God from their salvation history. Thus, the model in this psalm differs from the model of Israel's salvation history speaks of. Thus, there is a big gap between the "is", how they experience God as a parent, and the "is 
not", how they want to experience God. In this communal lament they try to persuade God to once again be the God of their salvation history. The models of the past, in which God is a loving and affectionate parent, are placed beside the current model, to emphasise the schism they are experiencing. This does not mean that Israel wants to abandon their faith and relationship with God, for there is still hope. The relationship is not lost, and thus the lament ends with hope and a knowing that God can, at any moment, return to them, and this will mean that they are saved.

In our present-day context, this psalm and its model could motivate believers to express their true feelings to God. Many people ask, where is God? during times of crisis and fear and they wonder why God has not yet acted to bring salvation to his followers. If their understanding is that they may only praise God and not accuse God, they might come to feel that God is absent or wicked in leaving his people in times of crises. In laments the verbalising of pain and the expression of hope after suffering strengthens the relationship with God, instead of breaking it down.

In this article I set out to show that the metaphors of Psalm 80 build a parenthood model. This model is a relational one, with God as the parent and Israel as the child. I did this by looking at the context and the literature type. This showed that Israel was in a context of uncertainty and that this communal lament helped them to express their pain and their trust that they were still in a relationship with God. The theology of the psalm emphasises the salvation history of Israel as the reason why they experienced a gap between their current experience of God and the experience they wanted. The theology of the refrain also emphasised the hope that was still in place and strengthened them to keep on believing and trusting that this was not their end.

\section{BIBLIOGRAPHY}

Basson, A. 2005. Divine metaphors in a selection of biblical Hebrew Psalms of lamentation. PhD dissertation, Stellenbosch University.

Bosworth, D.A. 2013. Weeping in the Psalms, Vetus Testamentum 63(1):36-46.

Briggs, C.A. and Briggs, E.G. 1906. A critical and exegetical commentary on the Book of Psalms. Edinburgh: T \& T Clark Ltd.

Brown, W.P. 2002. Seeing the Psalms: A theology of metaphors. London: Westminster John Knox Press.

Broyles, C.C. 1989. The conflict of faith and experience in the Psalms: A form-critical and theological study, Journal for the study of the Old Testament supplement series no. 52. Sheffield: Sheffield Academic Press.

Dahood, M.S.J. 1986. Psalms II: 51 - 100. In The Anchor Bible no. 17. New York: Doubleday \& Company, Inc.

Fretheim, T.E. 1984. The suffering of God: An Old Testament perspective. Philadelphia: Fortress Press.

Gaebelein, F.E. and Polcyn, R.P. (eds). 1991. The expositor's Bible commentary: Psalms - Song of Songs. Vol. 5. Grand Rapids: Zondervan Pub. House.

Gerstenberger, E.S. 2001. Psalms part 2 and Lamentations. In The forms of the Old Testament Literature no. XV. Grand Rapids: William B. Eerdmans Publishing Company. 
Greenstein, E.L. and Preminger, A. 1986. The Hebrew Bible in literary criticism. New York: The Ungar Publishing Company.

Hill, D. 1973. "Son of Man" in Psalm 80 v.17, Novum Testamentum 15(4):261-269.

Hossfeld, F. and Zenger, E. 2005. Psalms 2: A Commentary on Psalms 51-100. Trans.

L.M. Maloney. In Hermeneia: A critical and historical commentary on the Bible. Minneapolis: Fortress Press.

Jasper, F.N. 1967. Early Israelite traditions and the Psalter, Vetus Testamentum 17(1):50-59.

Lakoff, G. and Johnson, M. 1980. Metaphors we live by. Chicago: The University of Chicago Press.

Macky, P.W. 1990. The centrality of metaphors to Biblical thought: A method for interpreting the Bible. In Studies in the Bible and Early Christianity no. 19. Lewiston: The Edwin Mellen Press.

McFague, S. 1982. Metaphorical theology: Models of God in religious language. London: Fortress Press.

Rendsburg, G.A. 1990. Linguistic evidence for the Northern origin of selected Psalms. In Society of Biblical Literature Monograph Series no. 43. Atlanta: Scholars Press.

Rofe, A. 2011. The text-criticism of Psalm 80 - Revisited, Vetus Testamentum 61:298309.

Soskice, M.J. 1989. Metaphor and religious language. Oxford: Clarendon Press.

Tate, M.E. 1990. Psalms 51-100. In Word Biblical commentary no. 20. Dallas: Word Books Publishers.

Weiser, A. 1962. The Psalms: A commentary. London: SCM Press Ltd.

Wesselschmidt, Q.F. 2014. Psalms 51-150. In Ancient Christian commentary on Scripture: Old Testament no. VIII. Downers Grove: InterVarsity Press.

Westermann, C. 1981. Praise and lament in the Psalms. Trans. K.R. Crim and R.N. Soulen. Edinburgh: T \& T Clark Ltd.

Westermann, C. 1989. The living Psalms. Trans. J.R. Porter. Grand Rapids: William B. Eerdmans Publishing Company.

Whitekettle, R. 2005. Bugs, bunny, or boar? Identifying the Ziz animals of Psalms 50 and 80, The Catholic Biblical Quaterly 67:250-264. 